\title{
Unusual case of spontaneous pyomyoma in a perimenopausal woman
}

\author{
Catarina Peixinho (1), ${ }^{1}$ Ana Catarina Silva ${ }^{2}$
}

${ }^{1}$ Department of Obstetrics and Gynecology, Hospital Pedro Hispano, Matosinhos, Portugal 2Department of Imagiology, Hospital Pedro Hispano, Matosinhos, Portugal

\section{Correspondence to} Dr Catarina Peixinho: catarina.peixinho1989@gmail. com

Accepted 19 November 2020

Check for updates

(c) BMJ Publishing Group Limited 2020. No commercial re-use. See rights and permissions. Published by BMJ.

To cite: Peixinho $C$, Silva AC. BMJ Case Rep 2020:13:e240031. doi:10.1136/bcr-2020240031

\section{DESCRIPTION}

Pyomyoma is a rare but life-threatening condition that results from the infarction and infection of uterine leiomyoma. ${ }^{1}$ The most likely cause of pyomyoma is vascular compromise, followed by bacterial seeding from direct, haematogenous or lymphatic spread. Cases in postmenopausal women result from immune or vascular compromise, such as diabetes, hypertension or atherosclerotic disease.

Diagnosis of pyomyoma is difficult; it is a relatively rare condition and may develop over an extended period, which contributes to delayed diagnosis and mortality. ${ }^{2}$ A serious complication of a pyomyoma is its spontaneous rupture, which presents as an acute abdomen with septicemic shock. ${ }^{3}$ Patients typically present a triad of symptoms: sepsis, presence of leiomyoma and the absence of any other source of infection associated with abdominal pain and fever. However, it may present with other silent or non-specific symptoms. In perimenopausal and postmenopausal women, a large pyomyoma can be difficult to distinguish from a gynaecological malignant tumour, particularly in perimenopausal, cachectic women with nonspecific clinical presentation and without a history of leiomyoma. ${ }^{1}$ The patient in the case presented here, a perimenopausal woman who presented with anaemia, severe inflammatory reaction and abdominal pain, experienced a rare example of large uterine pyomyoma.

A 51-year-old nullipara woman was referred to the intensive medical care unit due to gradual-onset abdominal pain, fever and diarrhoea which had started 3 days previously.

The patient had a personal history of obesity (body mass index $>40 \mathrm{~kg} / \mathrm{m}^{2}$ ) and a cognitive deficit secondary to childhood bacterial meningitis and,

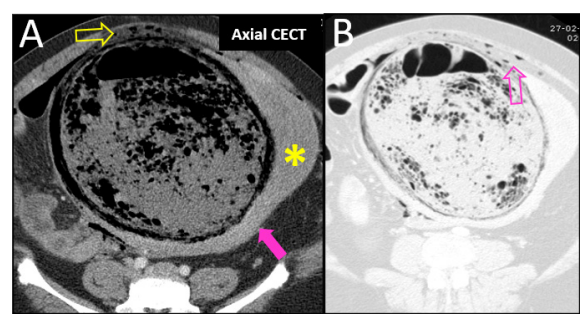

Figure 1 Axial CT scan shows that the mass corresponds to a large infected myoma, as demonstrated by the presence of large amounts of air inside the mass. The air and infection has already migrated to the peritoneal cavity (outline arrows). The uterine body is compressed by the mass (asterix). The beak sign is present (large solid arrow). CECT, contrast-enhanced CT.

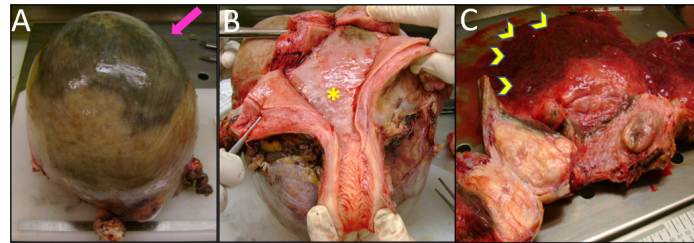

Figure 2 Gross specimen of the uterus shows: (A) the dark green serosal surface of the pyomyoma (white arrow); (B) the mass that compresses the uterus, as shown in the open uterine cavity (asterix). (C) The content of the infected myoma is seen spread in the table (arrowheads). It is mainly haemorrhagic but has a foul odour due to infection. Histology confirmed an extensive necrotic and infected leiomyoma.

in addition, had a diagnosis of bipolar disorder. Because of this background, the patient did not have previous routine examinations, namely, transvaginal ultrasound. The patient had no sexual activity and her last period would have been about 6 months ago.

At admission, the patient presented a body temperature of $38^{\circ} \mathrm{C}$, distended abdomen with a painful mass that was palpable at the abdomen (hypogastric zone). There was no vaginal discharge. Blood tests were performed and revealed a haemoglobin level of $98 \mathrm{~g} / \mathrm{L}$, white cell count was $12.3 \times 10^{9} / \mathrm{L}$ and $\mathrm{C}$ reactive protein was elevated to $526 \mathrm{mg} / \mathrm{dL}$, renal dysfunction (creatinine value of $1.7 \mathrm{mg} / \mathrm{dL})$.

A contrast CT scan was performed, revealing a $21 \mathrm{~cm}$ bulky pelvic mass containing air and air in the periphery. An axial CT scan showed that the mass probably corresponded to a large infected myoma, as demonstrated by the presence of large amounts of air inside the mass. The air and infection had already migrated to the peritoneal cavity (figure 1). The patient underwent an exploratory

\section{Learning points}

A high index of suspicion is required because pyomyomas are rare. They result from infarction and infection of a leiomyoma.

- In the present case, contrast CT contributed to the diagnosis. The presence of gas in uterine leiomyoma, as seen in this patient, is diagnostic for pyomyoma.

- Most of the described cases in literature required abdominal exploration and total abdominal hysterectomy or myomectomy and aggressive antibiotic treatment. 
laparotomy with a total abdominal hysterectomy and bilateral salpingo-oophorectomy. An unperforated mass was observed on the back wall of the uterus. Intraoperative findings confirmed a solid tumour. The resected uterus weighed $4770 \mathrm{~g}$ and measured $24 \times 21 \times 28 \mathrm{~cm}$, the anterior wall was coated with greenish smooth serosa (figure $2 \mathrm{~A}$ ). The anterior wall was deformed by a $21 \times 18 \mathrm{~cm}$ extensively necrotic, softened, foul smelling nodule (figure 2B). Histological examination revealed leiomyomas with almost complete infarction, widely necrotic with an inflammatory peripheral border in the transition between the preserved and necrotic tumour (figure 2C). The patient was hospitalised for 23 days ( 5 days in intensive care, 1 day in intermediate care, 17 days in the gynaecology department). The patient was discharged from the hospital well.

The images contained in this report demonstrate an unusual case of spontaneous pyomyoma in the absence of risk factors (no history of diabetes mellitus, hypertension, prior uterine instrumentation, or recent childbirth).
Contributors $\mathrm{CP}$ wrote the manuscript for publication. ACS made diagnostic imaging, selected and described all images.

Funding The authors have not declared a specific grant for this research from any funding agency in the public, commercial or not-for-profit sectors.

Competing interests None declared.

Patient consent for publication Obtained.

Provenance and peer review Not commissioned; externally peer reviewed.

\section{ORCID iD}

Catarina Peixinho http://orcid.org/0000-0001-5227-612X

\section{REFERENCES}

1 Iwahashi N, Mabuchi Y, Shiro M, et al. Large uterine pyomyoma in a perimenopausal female: a case report and review of 50 reported cases in the literature. Mol Clin Oncol 2016;5:527-31.

2 Gupta A, Gupta MM, Manaktala U. Ascending infection causing pyomyoma in a young woman. The Egyptian Journal of Radiology and Nuclear Medicine 2014;45:1017-20.

3 Yeat S-K, Chong K-M, Pan H-S, et al. Impending sepsis due to a ruptured pyomyoma with purulent peritonitis: a case report and literature review. Taiwanese Journal of Obstetrics and Gynecology 2005;44:75-9.

Copyright 2020 BMJ Publishing Group. All rights reserved. For permission to reuse any of this content visit https://www.bmj.com/company/products-services/rights-and-licensing/permissions/

BMJ Case Report Fellows may re-use this article for personal use and teaching without any further permission.

Become a Fellow of BMJ Case Reports today and you can:

- Submit as many cases as you like

- Enjoy fast sympathetic peer review and rapid publication of accepted articles

- Access all the published articles

- Re-use any of the published material for personal use and teaching without further permission

Customer Service

If you have any further queries about your subscription, please contact our customer services team on +44 (0) 2071111105 or via email at support@bmj.com.

Visit casereports.bmj.com for more articles like this and to become a Fellow 